Vol. 2, No.1, Januari - Juni 2017

ISSN : 2502-4736

Fakultas Pertanian UNIVERSITAS TRIDINANTI

PALEMBANG

$\frac{3}{3}$

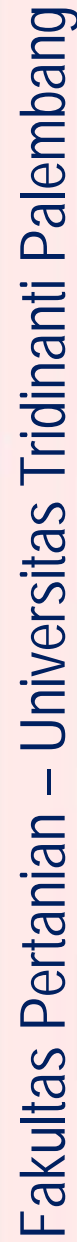

G)
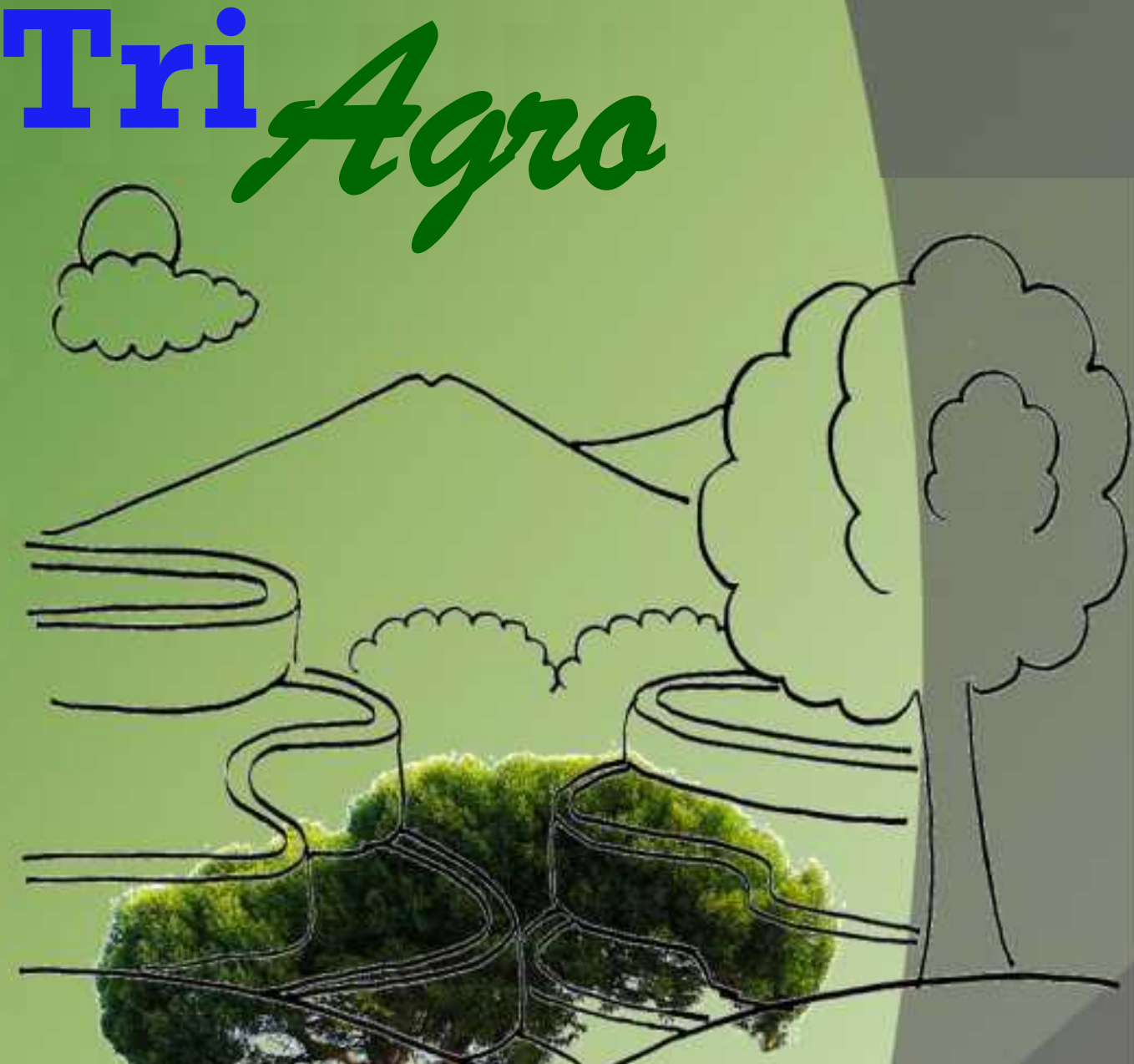

JURNAL Trišrgea

Alamat Redaksi : Fakultas Pertanian Universitas Tridinanti Jalan Kapten Marzuki No, 2446 Kamboja Palembang 30129 Telp. 0711-378387 


\section{Jurnal TRIAGRO}

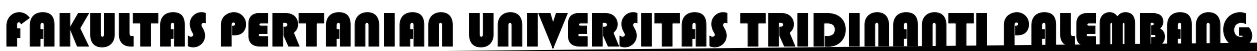

\section{Dewan Redaksi}

Pelindung

Pembina

Pimpinan Umum

Ketua Penyunting

Penyunting Pelaksana

Penyunting Ahli

Dewan Redaksi

Distribusi \& Website
: Dr. Ir. Hj. Manisah MP (Rektor)

: Dr. Nasir Sp. M.Si

: Miranty Trinawaty SP. M.Si

: Prof. Dr. Edizal M.S

- Prof. Dr. Edizal M.S

- Dr.Ir Faridatul Mukminah M.Sc

- Dr. Ir Ruarita RK. MP

: 1. Dr. Ir. Nurmayulis, MP (Universitas Sultan Ageng

Tirtayasa)

2. Dr. Munajat, SP. M.Si (Universitas Baturaja)

:

- Ir. Setiawaty MP

- Ir. Meryanto, M.Si

- Ir. Rostian Nafery, M.Si

- Ir. Ursula Damayanti, MP

- Ir. Ekanovi Aktiva, MM

- Ir. Hj. Yuliantina Azka, MP

: Nova Tri Buyana, Sp 


\section{DAFTAR ISI}

1 RESPON EKSPLAN TANAMAN KENTANG (Solanum tuberrosum L.)

VARIETAS GRANOLA TERHADAP DOSIS PUPUK DAUN DAN KONSENTRASI AIR KELAPA

Rostian Nafery, Zulkarnain Husny, Wendri Pranata *).

2 RESPON PERTUMBUHAN DAN HASIL TANAMAN JAGUNG MANIS

6

(Zea mays saccharata Sturt.) AKIBAT PEMBERIAN BERBAGAI DOSIS

PUPUK ORGANIK CAIR

Ruarita R.K, Ridwan Hanan, Achmad W.A

3 PENGARUH PEMBERIAN ZAT PENGATUR TUMBUH (ZPT)

TERHADAP PERTUMBUHAN DAN HASIL TANAMAN JAGUNG

MANIS (ZEA MAYS SACCHARATA STURT.)

Yuliantina Azka, Meriyanto, Yogi Romadi

PENGARUH PEMBERIAN LIMBAH LUMPUR KERING KELAPA

4 SAWIT TERHADAP PERTUMBUHAN DAN PRODUKSI TANAMAN

TOMAT (Solanum lycopersicum L.)

Bastani Sepindjung, Faridatul Mukminah, Henry Ardiansyah

PENGARUH PEMBERIAN BERBAGAI KONSENTRASI LARUTAN

NUTRISI HIDROPONIK TERHADAP PERTUMBUHAN DAN HASIL

TANAMAN SELADA MERAH (Lactuca sativa L.)DENGAN SISTEM Deep

Flow Technique (DFT)

Meriyanto, Busroni Asnawi, Sari Apriyani

6 PENGARUH PEMBERIAN LARUTAN NUTRISI HIDROPONIK

DENGAN BERBAGAI KONSENTRASI TERHADAP PERTUMBUHAN

DAN HASIL TANAMAN SELADA MERAH (Lactuca sativa L.) DENGAN SISTEM DEEP FLOW TECHNIQUE (DFT)

Meriyanto, Bastani Sepindjung, Rinti Mandasari. 


\section{Pedoman Penulisan Artikel Ilmiah \\ Jurnal TRIAgro \\ Fakultas Pertanian Universitas Tridinanti Palembang}

1. Jurnal ini direncanakan terbit tiga kali dalam setahun, terbuka untuk umum yang ingin mempublikasikan hasil karyanya. Artikel yang ditulis meliputi hasil penelitian di bidang sains.

2. Semua naskah makalah disertai pernyataan bahwa naskah tersebut belum pernah diterbitkan sebelumnya oleh penerbit lain.

3. Setiap naskah yang diterima akan ditinjau/ditelaah oleh ahli dibidangnya sebelum diterbitkan.

4. Naskah tidak dapat diterima jika mengandung unsur politik, komersialisme dan subyektifitas yang berlebihan.

5. Simbol dan terminologi yang digunakan adalah simbol dan terminologi yang lazim digunakan di bidang keahlian masin-masing.

6. Penulis menyetujui untuk mengalihkan hak ciptanya ke redaksi, jika naskahnya diterima untuk diterbitkan.

7. Artikel ditulis dalam bahasa Indonesia atau Inggris. Minimal 10 halaman dan maksimal 15 halaman, termasuk daftar pustaka dan lampiran : ukuran kertas A4, spasi 1,5, margin kiri $4 \mathrm{~cm}$, margin kanan, atas dan bawah masing-masing $3 \mathrm{~cm}$, menggunakan Times New Roman Font 11.

8. Artikel diketik dengan program MS Word, penulis dimohon mengirimkan satu print out dan satu CD yang berisi artikel, cantumkan alamat email dan no telepon/hp penulis untuk keperluan konfirmasi tentang tulisan yang dikirimkan ke redaksi.

9. Artikel dilengkapi :

Abstrak tidak lebih dari 200 kata dengan kata-kata kunci, biodata singkat penulis dan identitas penelitian dicantumkan sebagai cat kaki pada halaman pertma artikel.

10. Penulisan daftar pustaka mengikuti penulisan yang baik dan benar 


\section{KATA PENGANTAR}

Terima kasih atas berkah Tuhan Yang Maha Kuasa dan Rahmat-Nya, maka Jurnal TriAgro Fakultas Pertanian Universitas Tridinanti Palembang ini dapat diterbitkan. Jurnal ini diharapkan dapat menampung informasi dunia pertanian modern dan menyebarkan informasi di lingkup pertanian baik secara umum maupun khusus, penerbitan jurnal ini diharapkan dapat menjadi sarana untuk menampung tulisan-tulisan ilmiah pertanian.

Dewan redaksi mengucapkan terima kasih kepada semua pihak yang telah memerikan bantuan teknis maupun non teknis untuk terbitnya jurnal TriAgro ini. Dewan redaksi sangat mengharapkan partisipasi peneliti untuk menyumbangkan tulisannya ke jurnal TriArgro ini guna menjaga kelancaran penerbitan, yaitu dua kali setahun.

Dewan redaksi mengucapkan terima kasih kepada Bapak/Ibu/Saudara yang telah berpartisipasi pada jurnal edisi ini. Semoga Jurnal ini dapat memberikan manfaat kepada Bapak/Ibu/Saudara semuanya. 


\title{
PENGARUH PEMBERIAN ZAT PENGATUR TUMBUH (ZPT) TERHADAP PERTUMBUHAN DAN HASIL TANAMAN JAGUNG MANIS (ZEA MAYS SACCHARATA STURT.)
}

\section{EFFECT OF PLANT GROWTH REGULATORS (PGR) ON THE GROWTH AND YIELD OF SWEET CORN (ZEA MAYS SACCHARATA STURT.)}

\author{
YULIANTINA AZKA ${ }^{1}$, MERIYANTO ${ }^{2}$, YOGI ROMADI ${ }^{3}$ \\ ${ }^{12}$ Dosen Program Studi Agroteknologi, ${ }^{3}$ Mahasiswa Program Studi Agroteknologi \\ Program Studi Agroteknologi, Fakultas Pertanian, Universitas Tridinanti Palembang \\ Jl. Kapten Marzuki No.2445, Kamboja, Palembang30129
}

\begin{abstract}
This research was aimed to determine the effect of plant growth regulator on the growth and yield ofsweet corn. This research was conducted in Lalang Sembawa village, Sembawa subdistrict, Banyuasin Regency, South Sumatera. The research was conducted from December 2014 up to March 2015. This research used a randomized block design (RBD) with 6 treatments and 4 replications. The treatments researced were: $\mathrm{P} 0=0 \mathrm{ml} / \mathrm{l}$ of water (Control), $\mathrm{P} 1=4 \mathrm{ml} / \mathrm{l}$ of water, $\mathrm{P} 2=8 \mathrm{ml} / 1$ of water,P3 $=12 \mathrm{ml} / 1$ of water, $\mathrm{P} 4=16$ $\mathrm{ml} / \mathrm{l}$ of water, and $\mathrm{P} 5=20 \mathrm{ml} / 1$ of water.. The variables observation is plant's height $(\mathrm{cm})$, number of leaves (strand), flowering age (dap), number of corncobs in per plant (cob), number of corncobs in per field (cob), weight of corncobs per plant $(\mathrm{g})$, weight of corncobs per field $(\mathrm{g})$, corncob diameters $(\mathrm{cm})$ and corncob lenght $(\mathrm{cm})$. The results showed that application $12 \mathrm{ml} / 1$ water of plant growth regulator was give the highest growth and yield of sweet corn with produce the plant's height $186,96 \mathrm{~cm}$, number of leaves 12,25 strand, flowering age at 52,50 day after plant, weight of corncob per plant 569,17 g and weight of corncob per field 7807,5 $\mathrm{g}$.
\end{abstract}

Keywords : Sweet Corn, Plant Growth Regulator, Yield,

\section{ABSTRAK}

Penelitian bertujuan untuk mengetahui pengaruh pemberian zat pengatur tumbuh terhadap pertumbuhan dan hasil tanaman jagung manis. Penelitian dilakukan di desa Lalang Sembawa Kabupaten Banyuasin Sum-Sel, dimulai pada bulan Desember 2014 sampai bulan April 2015. Penelitian menggunakan RAK dengan 6 perlakuan dan 4 ulangan, perlakuan yang diteliti yaitu: $\mathrm{P} 0=0 \mathrm{ml} / \mathrm{l}$ air (Kontrol), $\mathrm{P} 1=4 \mathrm{ml} / \mathrm{l}$ air, $\mathrm{P} 2=8 \mathrm{ml} / \mathrm{l}$ air, $\mathrm{P} 3=12 \mathrm{ml} / \mathrm{l}$ air, $\mathrm{P} 4=16 \mathrm{ml} / \mathrm{l}$ air, dan $\mathrm{P} 5=20 \mathrm{ml} / \mathrm{l}$ air. Peubah yang diamati yaitu tinggi tanaman $(\mathrm{cm})$, jumlah daun (helai), umur berbunga (hari), jumlah tongkol per tanaman, jumlah tongkol per petak, berat tongkol per tanaman, berat tongkol per petak, diameter tongkol $(\mathrm{cm})$ dan panjang tongkol $(\mathrm{cm})$. Hasil penelitian menunjukkan bahwa pemberian ZPT $12 \mathrm{ml} / \mathrm{l}$ air memberikan pengaruh yang lebih baik terhadap pertumbuhan dan hasil tanaman jagung manis dengan menghasilkan tinggi tanaman $186.96 \mathrm{~cm}$, jumlah daun 12.25 helai, umur berbunga 52.5 hari, berat tongkol per tanaman $569.17 \mathrm{~g}$ dan berat tongkol per petak $7807.5 \mathrm{~g}$.

1) Staf Dosen Fakultas Pertanian UTP

2) Alumni Fakultas Pertanian UTP

PENDAHULUAN

Jagung telah dibudidayakan di Amerika Tengah (Meksiko Bagian Selatan) sekitar 8000 tahun sampai 10000 
tahun yang lalu, berawal dari ditemukan fosil tongkol jagung dengan ukuran kecil yang diperkirakan usianya mencapai sekitar 7000 tahun. Menurut pendapat beberapa ahli botani, teosinte (Zea mays sp. Parviglumis) sebagai nenek moyang tanaman jagung, merupakan tumbuhan liar yang berasal dari lembah Sungai Balsas, lembah di Meksiko Selatan. Bukti genetik, antropologi, dan arkeologi menunjukkan bahwa daerah asal jagung adalah Amerika Tengah dan dari daerah ini jagung tersebar dan ditanam di seluruh dunia (Iriany, Yasin, dan Takdir, 2008).

Di Indonesia, daerah-daerah penghasil utama tanaman jagung adalah Jawa Barat, Jawa Tengah, Jawa Timur, Madura, Daerah Istimewa Yogyakarta, Nusa Tenggara Timur, Sulawesi Utara, Sulawesi Selatan, dan Maluku. Khusus di daerah Jawa Timur dan Madura, budidaya tanaman jagung dilakukan secara intensif karena kondisi tanah dan iklimnya sangat mendukung untuk pertumbuhannya.

Tanaman jagung secara spesifik merupakan tanaman pangan yang sangat bermanfaat bagi kehidupan manusia ataupun hewan. Jagung merupakan makanan pokok kedua setelah padi di Indonesia. Berdasarkan urutan bahan makanan pokok di dunia, jagung menduduki urutan ketiga setelah gandum dan padi. Tanaman jagung hingga kini dimanfaatkan oleh masyarakat dalam berbagai bentuk penyajian, seperti tepung jagung (maizena), minyak jagung, bahan pangan, serta sebagai pakan ternak dan lain lainnya (Iriany, Yasin, dan Takdir, 2008).

Menurut Sudarsono (2000), kebutuhan jagung manis nasional untuk pangan rata - rata 7 ton/ha/tahun - 8 ton/ha/tahun, sedangkan produksi jagung manis dalam negeri rata - rata 5 ton/ha/tahun - 6 ton/ha/tahun. Di Indonesia hasil jagung manis masih tergolong rendah yaitu 3,5 ton/ha/tahun, sedangkan potensi produksi jagung manis saat ini dapat mencapai 8,31 ton/ha/tahun. Salah satu penyebab rendahnya tingkat produktivitas komoditas pertanian, khususnya jagung manis ialah kondisi kesuburan tanah yang menurun dan bahan organik tanah yang rendah.

Keberhasilan peningkatan produktivitas komoditas pertanian di Indonesia tidak terlepas dari penggunaan pupuk anorganik secara berlebihan. Penggunaan pupuk anorganik secara terusmenerus tanpa diimbangi oleh pupuk organik akan memberikan pengaruh buruk pada tanah. Penggunaan pupuk anorganik secara intensif untuk mengejar hasil yang tinggi akan menyebabkan bahan organik tanah menurun, sehingga produktivitas lahan juga menurun. Sejalan dengan peningkatan kesadaran manusia akan dampak dari penggunaan pupuk anorganik, maka upaya yang dapat dilakukan ialah dengan penggunaan pupuk hayati yang dapat menjadi salah satu alternatif yang baik untuk memperbaiki sifat tanah serta menambah kandungan unsur hara pada tanah sehingga produktivitas jagung manis masih dapat ditingkatkan ataupun dengan menggunakan zat pengatur tumbuh yang dapat mengembangkan pertumbuhan tanaman.

$\begin{array}{rrr} & \text { Penelitian ini ingin membuktikan } \\ \text { apakah } & \text { ZPT } \quad \text { (Hormax) mampu }\end{array}$ meningkatkan pertumbuhan dan produksi tanaman jagung manis. Oleh karena itu, peneliti tertarik untuk melakukan penelitian dengan judul Pengaruh Pemberian Zat Pengatur Tumbuh (ZPT) terhadap Pertumbuhan dan Hasil Tanaman Jagung Manis, dengan mengacu pada penelitian sebelumnya yang dilakukan Darmawi (2014) pada stum mata tidur karet klon IRR 112. Perlakuan konsentrasi Zat Pengatur Tumbuh $12 \mathrm{ml} / 1$ air cenderung memberikan hasil yang terbaik terhadap panjang tunas $35,17 \mathrm{~cm}$, berat berangkasan basah akar 3,82 g dan berat berangkasan kering akar 2,04 g.

Tujuan penelitian ini adalah untuk mengetahui pengaruh pemberian ZPT terhadap pertumbuhan dan hasil tanaman jagung manis. Penelitian ini diharapkan dapat menjadi sumber pengetahuan dan 
teknologi tentang penggunaan ZPT yang terbaik untuk pertumbuhan dan produksi tanaman jagung manis serta dapat digunakan sebagai pedoman bagi masyarakat yang ingin membudidayakan tanaman jagung manis. Diduga pemberian zat pengatur tumbuh dengan dosis $12 \mathrm{ml} / \mathrm{l}$ air berpengaruh baik terhadap pertumbuhan dan hasil tanaman jagung manis.

\section{BAHAN DAN METODE}

Penelitian ini telah dilaksanakan di

Desa Lalang Sembawa, Kecamatan Sembawa, Kabupaten Banyuasin, Provinsi Sumatera Selatan, dari bulan Desember 2014 sampai dengan bulan Maret 2015. Bahan yang digunakan dalam penelitian ini adalah 1). Benih jagung manis, 2). Fungisida, 3). Pupuk majemuk NPK, dan 4). ZPT Hormax. Alat yang digunakan dalam penelitian ini antara lain adalah 1). Cangkul, 2). Ember, 3). Gembor, 4). Gelas ukur, 5). Hand Sprayer dan 6). Parang. Rancangan yang digunakan yaitu Rancangan Acak Kelompok (RAK) dengan 6 perlakuan dan 4 ulangan. Perlakuan yang diuji sebagai berikut : P0 $=0 \mathrm{ml} / \mathrm{l}$ air (kontrol), $\mathrm{P} 1=4 \mathrm{ml} / \mathrm{l}$ air, $\mathrm{P} 2=8 \mathrm{ml} / \mathrm{l}$ air, $\mathrm{P} 3=12 \mathrm{ml} / \mathrm{l}$ air, $\mathrm{P} 4=$ $16 \mathrm{ml} / \mathrm{l}$ air dan P5 = $20 \mathrm{ml} / \mathrm{l}$ air. Setiap unit perlakuan terdiri dari 20 tanaman, maka jumlah tanaman yang diteliti sebanyak 480 tanaman. Cara kerja yang dilakukan dimulai dengan pengolahan tanah, pembuatan galangan dan pemberian pupuk dasar, persiapan perlakuan dan pemberian ZPT, penanaman, pemeliharaan yang meliputi penyiraman, penjarangan dan penyulaman, penyiangan, pembumbunan, dan pengendalian HPT serta panen. Peubah yang diamati dalam penelitian ini yaitu tinggi tanaman $(\mathrm{cm})$, jumlah daun (helai), umur berbunga (hst), jumlah tongkol per tanaman (tongkol), jumlah tongkol per petak (tongkol), berat jumlah tongkol per tanaman $(\mathrm{g})$, berat tongkol per petak $(\mathrm{g})$, diameter tongkol $(\mathrm{g})$ dan panjang tongkol $(\mathrm{cm})$.

\section{HASIL DAN PEMBAHASAN}

\section{Hasil}

Hasil analisis keragaman terhadap semua peubah yang diamati tertera pada Tabel 1. Hasil uji F-Hitung Tabel 1 menunjukkan bahwa pemberian Zat Pengatur Tumbuh berpengaruh nyata sampai sangat nyata terhadap semua peubah, kecuali jumlah tongkol per tanaman, jumlah tongkol per petak, panjang tongkol dan diameter tongkol.

\section{Tinggi Tanaman}

Hasil analisis keragaman pada Tabel 1 menunjukkan bahwa, pemberian zat pengatur tumbuh berpengaruh sangat nyata terhadap tinggi tanaman 2 MST, 4 MST, dan 6 MST serta berpengaruh nyata terhadap tinggi tanaman 8 MST.

Hasil Uji Beda Nyata BNJ taraf 5 $\%$ pada peubah tinggi tanaman umur 2 MST, 4 MST, 6 MST, dan 8 MST secara berurut dapat dilihat pada Tabel 2 .

Berdasarkan Tabel 2 di atas tampak bahwa, pemberian zat pengatur tumbuh 12 $\mathrm{ml} / \mathrm{l}$ air (P3) menghasilkan tinggi tanaman pada 2 MST, 6 MST dan 8 MST yang berbeda nyata dibandingkan dengan perlakuan P0 (kontrol) dan P1 (4 ml/l air), sedangkan terhadap perlakuan lain berbeda tidak nyata. Pada umur 4 MST perlakuan P3 menghasilkan tinggi tanaman yang berbeda nyata dibandingkan dengan perlakuan kontrol, sedangkan terhadap perlakuan lain berbeda tidak nyata.

\section{Jumlah Daun}

Hasil analisis keragaman pada Tabel 1 menunjukkan bahwa, pemberian zat pengatur tumbuh berpengaruh sangat nyata terhadap jumlah daun 2 MST, 4 MST, dan 8 MST serta berpengaruh nyata terhadap jumlah daun 6 MST. Hasil Uji BNJ taraf 5 $\%$ pada jumlah daun umur 2 MST, 4 MST, 6 MST, dan 8 MST secara berurut dapat dilihat pada Tabel 3. 
Tabel 1. Hasil analisis keragaman terhadap semua peubah yang diamati.

\begin{tabular}{lcc}
\hline \multicolumn{1}{c}{ Peubah Yang Diamati } & F- Hitung & KK $(\%)$ \\
\hline Tinggi Tanaman & & \\
2 MST & $8,31^{* *}$ & 14,23 \\
4 MST & $5,55^{* *}$ & 7,41 \\
6 MST & $10,9^{* *}$ & 13,33 \\
8 MST & $4,06^{*}$ & 4,81 \\
Jumlah Daun & & \\
2 MST & $7,2^{* *}$ & 8,4 \\
4 MST & $8,17^{* *}$ & 5,22 \\
6 MST & $3,63^{*}$ & 6,93 \\
8 MST & $5,4^{* *}$ & 5,56 \\
Umur Berbunga & $5,83^{* *}$ & 1,06 \\
Jumlah Tongkol per Tanaman & $1,32^{\text {tn }}$ & 15,81 \\
Berat Tongkol per Tanaman & $4,24^{*}$ & 17,68 \\
Jumlah Tongkol per Petak & $1,91^{\text {tn }}$ & 13,22 \\
Berat Tongkol per Petak & $2,92^{*}$ & 24,92 \\
Panjang Tongkol & $0,57^{\text {tn }}$ & 4,3 \\
Diameter Tongkol & $0,58^{\text {tn }}$ & 5,45 \\
\hline F Tabel 5\% & 2,90 & \\
\hline
\end{tabular}

Keterangan:

$\begin{array}{llll}* & =\text { Berpengaruh nyata } & \text { tn } & =\text { Berpengaruh tidak nyata } \\ * * & =\text { Berpengaruh sangat nyata } & \mathrm{KK} & =\text { Koefisien Keragaman }\end{array}$

Tabel 2. Pengaruh pemberian zat pengatur tumbuh terhadap tinggi tanaman.

\begin{tabular}{crrrrrrrr}
\hline \multirow{2}{*}{ Perlakuan } & \multicolumn{3}{c}{2 MST } & \multicolumn{2}{c}{4 MST } & \multicolumn{2}{c}{6 MST } & \multicolumn{2}{c}{8 MST } \\
\hline P0 & 7,29 & a & 56,79 & A & 89,47 & a & 163,17 & a \\
P1 & 7,82 & a & 64,63 & Ab & 109,37 & ab & 167,07 & a \\
P2 & 9,66 & ab & 69,47 & B & 140,11 & bc & 178,56 & ab \\
P3 & 12,49 & b & 74,12 & B & 168,93 & c & 186,96 & b \\
P4 & 11,40 & b & 67,40 & Ab & 152,97 & c & 174,51 & ab \\
P5 & 9,85 & ab & 65,05 & Ab & 129,13 & abc & 173,05 & ab
\end{tabular}

Keterangan : Angka-angka yang diikuti oleh huruf yang sama menunjukkan beda tidak nyata berdasarkan uji BNJ 5\%

Tabel 3, Pengaruh pemberian zat pengatur tumbuh terhadap jumlah daun

\begin{tabular}{crrrrrrrr}
\hline Perlakuan & \multicolumn{2}{c}{2 MST } & \multicolumn{2}{c}{ 4 MST } & \multicolumn{2}{c}{ 6 MST } & \multicolumn{2}{c}{8 MST } \\
\hline P0 & 2,92 & a & 6,42 & A & 8,42 & A & 10,25 & a \\
P1 & 3,25 & ab & 6,42 & A & 8,92 & A & 10,58 & a \\
P2 & 3,42 & abc & 7,33 & B & 9,50 & Ab & 11,33 & ab \\
P3 & 4,00 & c & 7,75 & B & 9,83 & Ab & 12,25 & b \\
P4 & 3,83 & bc & 7,00 & Ab & 9,92 & B & 11,17 & ab \\
P5 & 3,58 & abc & 7,08 & Ab & 9,92 & B & 10,67 & b \\
\hline
\end{tabular}


Berdasarkan Tabel 3 tampak bahwa, pemberian zat pengatur tumbuh 12 $\mathrm{ml} / \mathrm{l}$ air (P3) menghasilkan jumlah daun pada 2 MST, 4 MST, 8 MST yang berbeda nyata dibandingkan perlakuan P0 (kontrol) dan P1 (4 ml/l air), sedangkan terhadap perlakuan lain berbeda tidak nyata. Pada umur 6 MST perlakuan P4 dan P5 menghasilkan tinggi tanaman yang berbeda nyata dibandingkan dengan perlakuan P0 (kontrol) dan P1, sedangkan terhadap perlakuan lain berbeda tidak nyata.

\section{Umur Berbunga}

Hasil analisis keragaman pada Tabel 1 menunjukkan bahwa, pemberian zat pengatur tumbuh berpengaruh sangat nyata terhadap umur berbunga. Hasil Uji BNJ taraf $5 \%$ dapat dilihat pada Tabel 4 . Pada
Tabel 4 tampak bahwa, pemberian zat pengatur tumbuh $12 \mathrm{ml} / \mathrm{l}$ air (P3) menghasilkan umur berbunga sebesar 52,50 hari yang berbeda nyata dibandingkan perlakuan P0 dan P1, sedangkan terhadap perlakuan lain berbeda tidak nyata.

\section{Berat Tongkol Per Tanaman}

Hasil analisis keragaman pada Tabel 1 menunjukkan bahwa pemberian zat pengatur tumbuh berpengaruh nyata terhadap berat tongkol per tanaman. Hasil Uji BNJ taraf $5 \%$ dapat dilihat pada Tabel 4. Pada Tabel 4 tampak bahwa, pemberian zat pengatur tumbuh $12 \mathrm{ml} / \mathrm{l}$ air (P3) menghasilkan berat tongkol per tanaman yaitu 569,17 g yang berbeda nyata dibandingkan perlakuan P0 (kontrol) dan P1 (4 ml/l air), sedangkan terhadap perlakuan lain berbeda tidak nyata.

Tabel 4. Pengaruh pemberian zat pengatur tumbuh terhadap umur berbunga, berat tongkol per tanaman dan berat tongkol per petak

\begin{tabular}{cccc}
\hline Perlakuan & $\begin{array}{c}\text { Umur Berbunga } \\
\text { (hari) }\end{array}$ & $\begin{array}{c}\text { berat tongkol per } \\
\text { tanaman }(\mathrm{g})\end{array}$ & $\begin{array}{c}\text { berat tongkol per } \\
\text { petak }(\mathrm{g})\end{array}$ \\
\hline P0 & $54,25 \mathrm{~b}$ & $391,25 \mathrm{a}$ & $4300,00 \mathrm{a}$ \\
P1 & $54,08 \mathrm{~b}$ & $340,00 \mathrm{a}$ & $4950,00 \mathrm{a}$ \\
P2 & $53,17 \mathrm{ab}$ & $468,75 \mathrm{ab}$ & $6900,00 \mathrm{ab}$ \\
P3 & $52,50 \mathrm{a}$ & $569,17 \mathrm{~b}$ & $7807,50 \mathrm{~b}$ \\
P4 & $53,00 \mathrm{ab}$ & $425,00 \mathrm{ab}$ & $6087,50 \mathrm{ab}$ \\
P5 & $53,00 \mathrm{ab}$ & $405,00 \mathrm{ab}$ & $5836,25 \mathrm{ab}$ \\
\hline BNJ 0,05 & 1,31 & 176,13 & 3427,64 \\
\hline
\end{tabular}

\section{Berat Tongkol Per Petak}

Hasil uji F-Hitung Tabel 1 menunjukkan bahwa, pemberian zat pengatur tumbuh berpengaruh nyata terhadap berat tongkol per petak. Hasil Uji BNJ taraf $5 \%$ pada peubah berat tongkol per petak dapat dilihat pada Tabel 4 .

Berdasarkan Tabel 4 tampak bahwa, pemberian zat pengatur tumbuh 12 $\mathrm{ml} / \mathrm{l}$ air (P3) menghasilkan berat tongkol per petak sebesar 7807,50 g yang berbeda nyata dibandingkan perlakuan P0 (kontrol), sedangkan terhadap perlakuan lain berbeda tidak nyata.

\section{Pembahasan}

Berdasarkan hasil analisis yang telah dilakukan pada semua peubah, sebagian besar menunjukan perlakuan berpengaruh nyata. Hasil analisis lanjut menggunakan BNJ rata-rata menunjukkan perlakuan pemberian dosis ZPT $12 \mathrm{ml} / \mathrm{l}$ air menghasilkan pengaruh yang terbaik pada sebagian besar peubah seperti tinggi tanaman, jumlah daun, berat tongkol per tanaman dan berat tongkol per petak.

Zat Pengatur Tumbuh merupakan senyawa organik yang bukan hara (nutrient) yang dapat ditambahkan dalam jumlah tertentu untuk mendukung, 
menghambat dan secara kualitatif merubah proses fisiologis tanaman (Widyastuti dan Tjokrokusumo, 2006). Zat pengatur tumbuh tanaman berperan penting dalam mengontrol proses biologi dalam jaringan tanaman (Gaba, 2005), perannya antara lain mengatur kecepatan pertumbuhan dari masing -masing jaringan dan mengintegrasi-kan bagian-bagian tersebut guna menghasikan bentuk yang kita kenal sebagai tanaman. Aktivitas zat pengatur tumbuh di dalam pertumbuhan tergantung dari jenis, struktur kimia, konsentrasi, genotype tanaman serta fase fisiologi tanaman (Satyavathi et al., 2004). Terlihat ada interaksi antara zat pengatur tumbuh eksogen yang ditambahkan ke tanaman dan zat pengatur tumbuh eksogen yang diproduksi sendiri oleh jaringan tanaman dalam proses pembentukan dan pertumbuhan organ seperti tunas dan pertambahan daun (Winata, 1987).

Hormon auksin merupakan hormon

yang bertanggung jawab terhadap percepatan pembelahan sel. Menurut Darnell (1986), auksin merupakan salah satu fitohormon yang mampu meregulasi banyak proses fisiologi dalam tanaman seperti pertumbuhan, pembelahan dan diferensiasi sel serta sintesa protein. Auksin sebagian besar diproduksi dalam jaringan merismatik aktif seperti tunasmuda (apical). Penambahan auksin ke tanaman, dapat meningkatkan konsentrasi zat pengatur tumbuh endogen di dalam sel, sehingga menjadi faktor pemicu dalam proses pertumbuhan tanaman (Poonsapaya et al., 1989).

Pemberian Auksin secara optimal mampu meningkatkan pembelahan sel di jaringan meristem, peningkatan pembelahan sel ini mampu mempercepat pertumbuhan tanaman, terutama tinggi tanaman. Pemberian ZPT dengan dosis 12 $\mathrm{ml} / \mathrm{l}$ air memberikan pertumbuhan tinggi yang optimal terhadap tanaman jagung. Berdasarkan uji lanjut BNJ pada Tabel 3, 4, 5 dan 6 , rata - rata perlakuan $12 \mathrm{ml} / 1$ menunjukan hasil terbaik pada peubah tinggi tanaman pada umur $2,4,6$ dan 8 MST.

Sitokinin merupakan salah satu hormon pada tanaman yang yang berfungsi dalam mendorong pembelahan (sitokinesis), meningkat-kan jumlah dan ukuran daun, serta menunda penuaan daun, bunga dan buah dengan cara mengontrol dengan baik proses kemunduran yang menyebabkan kematian sel tanaman (Campbellet al., 2002). Perlakuan $12 \mathrm{ml} / \mathrm{l}$ air berdasarkan analisis yang telah dilakukan menunjukan hasil optimal pada peubah jumlah daun. Berdasarkan hasil analisis BNJ pada Tabel 6, 7 dan 9 yaitu jumlah daun umur 2, 4 dan 8 MST menunjukan hasil terbaik dibanding perlakuan lain.

Sitokinin dan giberellin merupakan hormon yang diduga bertanggung jawab dalam mempercepat munculnya bunga (Campbell et al.,2002). Pemberian ZPT ini dalam jumlah optimal dapat mempercepat proses munculnya bunga terutama pada tanaman jagung. Berdasarkan tabel 4, pemberian ZPT dengan dosis $12 \mathrm{ml} / \mathrm{l}$ air menunjukan hasil terbaik pada peubah umur berbunga dengan rerata mampu berbunga pada umur 52,5 HST.

Hormax merupakan salah satu zat perangsang tumbuh organik yang dapat meningkatkan pertumbuhan dan produktivitas tanaman dengan dosis tertentu. Pemberian ZPT pada dosis 12 $\mathrm{ml} / \mathrm{l}$ air berdasarkan hasil analisis menunjukan hasil yang optimal terhadap hasil panen. Berdasarkan hasil uji lanjut BNJ pada Tabel 4 perlakuan $12 \mathrm{ml} / \mathrm{l}$ air menunjukan hasil terbaik dengan rerata berat tongkol per tanaman tertinggi yaitu $569,17 \mathrm{~g}$ dan rerata berat tongkol per petak yaitu $7807,5 \mathrm{~g}$.

\section{KESIMPULAN DAN SARAN}

\section{Kesimpulan}

Berdasarkan hasil penelitian yang diperoleh dapat disimpulkan bahwa pemberian zat pengatur tumbuh (hormax) dengan konsentrasi $12 \quad \mathrm{ml} / \mathrm{l}$ air 


\section{JURNAL TRIAGRO}

berpengaruh baik terhadap pertumbuhan dan hasil tanaman jagung manis yaitu menghasilkan tinggi tanaman $186,96 \mathrm{~cm}$, jumlah daun sebanyak 12,25 helai, umur berbunga 52,50 hari, berat tongkol per tanaman seberat $569,17 \mathrm{~g}$, dan berat tongkol per petak $7807,5 \mathrm{~g}$.

\section{Saran}

Pemberian zat pengatur tumbuh (Hormax) dengan dosis $12 \mathrm{ml} / \mathrm{l}$ air diharapkan dapat digunakan sebagai dosis anjuran dalam kegiatan budidaya tanaman jagung oleh petani untuk meningkatkan pertumbuhan dan hasil tanaman jagung.

\section{DAFTAR PUSTAKA}

Campbell, N. A. and J. B. Reece. 2002. Biology. Sixth Edition, Pearson Education. Inc. San Francisco. 802831.

Darmawi, Muhammad. 2014. Pengaruh Pemberian Zat Pengatur Tumbuh terhadap Pertumbuhan Stum Mata Tidur Karet Klon IRR 112 (Skripsi). Fakultas Pertanian Universitas Tridinanti Palembang. Palembang.

Darnell, J., H. Lodish and H. Baltimore. 1986. Molecular Cell Biology. Scientific American Books, Inc. New York.

Gaba, V.P. 2005. Plant Growth Regulator. In R.N. Trigiano and D.J. Gray (eds.) Plant Tissue Culture and Development. CRC Press. London. p. 87-100.

Gardner, P. Franklin,. Pearce, Brent R,.dan Mitchell, L. Roger. 1991. Fisiologi Tanaman Budidaya. Diterjemahkan oleh Herawati Susilo; pendamping Subiyanto.Universitas Indonesia Press. Jakarta
Iriany, Yasin, dan Takdir. 2008. Asal, Sejarah, Evolusi, dan Taksonomi Tanaman Jagung. Balai Penelitian Tanaman Serealia, Maros..

Poonsapaya, P.M.W, Nabors, W. Kersi, and M. Vajrabhaya. 1989. A comparison of methods for callus culture and plant regeneration of $\mathrm{RD}-25$ rice (Oryza sativa L.) in vitro laboratoris. Plant Cell Tiss. Org. Cult. 16:175-186.

Satyavathi, V.V., P.P. Jauhar, E.M. Elias, and M.B. Rao. 2004. Genomics, molecular genetic and biotechnology efects of growth regulators on in vitro plant regeneration. Crop Sci. 44:18391846.

Sudarsono, K. 2000. Pengaruh Efek Mikroorganisme-4 (EM-4) dan Kompos terhadap Pertumbuhan Jagung Manis (Zea mays saccharata Sturt) pada

Tanah Entisol. Frontir: 32.

Widyastuti, N. dan D. Tjokrokusumo. 2006. Peranan Beberapa Zat Pengatur Tumbuh (ZPT) Tanaman pada Kultur In Vitro. Jurnal Saint dan Teknologi BPPT. V3.n5.08

Winata, L. 1987. Teknik Kultur Jaringan. PAU Bogor. 252 hlm. 
